\title{
Raw Semen Characteristics of Three Different Indonesian Local Roosters
}

\author{
Emilia Kamung Hambu, Raden lis Arifiantini*, Bambang Purwantara and Sri Darwati \\ Faculty of Veterinary Medicine, Bogor Agricultural University \\ JIn Agatis , Kampus IPB Darmaga Bogor, Jawa Barat, Indonesia \\ Corresponding E-mail: iis.arifiantinipurna@gmail.com
}

\begin{abstract}
Indonesia has agreat variety of roosters, either indigenous type as well as exotic and cross breed. The purpose of this experiment was to study the characteristics of semen from three types of Indonesian local roosters such as Merawang, Kampung and crosses Sentul Kampung with Kedu (SK Kedu). A total of 15 roosters consist of Merawang roosters, Kampung, and SK Kedu roosters were 5 each. The semen was collected 3 times a week by dorso-abdominal and cloaca massage method. The parameters evaluation was macroscopic characteristics consist of volume, color, consistency, and $\mathrm{pH}$. Microscopic evaluation of semen such as a mass movement, sperm motility, live sperm, sperm abnormality and sperm concentration. Results of this experiment showed that semen volume of Merawang $(0.40 \pm 0.26 \mathrm{~mL})$ was higher $(p<0.05)$ compare to Kampung $(0.24 \pm 0.12 \mathrm{~mL})$ or SK Kedu $(0.16 \pm 0.10 \mathrm{~mL})$ but no difference on semen color, consistency and semen $\mathrm{pH}$. There were no difference in the mass movement, sperm motility and live sperm as well as on sperm abnormality among three types of roosters. Sperm concentration of Merawang (4490 million mL ${ }^{-1}$ ) was significantly higher than Kampung ( $3245{\text { million } \mathrm{mL}^{-1} \text { ) and the SK Kedu roosters (3751 million mL }}^{-1}$ ). Its was conclude that Merawang roosters had good semen quality better than Kampung and SK Kedu roosters.
\end{abstract}

Key words: characteristics, local roosters, semen

\begin{abstract}
Abstrak. Indonesia memiliki kekayaan besar varietas ayam meliputi tipe asli Indonesia dan impor serta persilangannya. Tujuan penelitian ini untuk mengkaji beberapa karakteritik semen dari tiga jenis ayam lokal yaitu Merawang, Kampung dan persilangan Sentul Kampung dengan Kedu (SK Kedu). Dilibatkan 15 ekor ayam, masing-masing terdiri dari 5 ekor Merawang, Kampung, dan SK Kedu. Koleksi semen dilakukan tiga kali dalam sepekan melalui metode pemijatan pada dorso-abdominal dan cloaca. Parameter yang diamati adalah karakterstik-karakteristik makrokospik (meliputi volume, warna, konsistensi dan pH) dan mikrokospik (meliputi pergerakan, motilitas, daya hidup, abnormalitas dan konsentrasi sperma). Hasil penelitian ini menunjukkan bahwa volume semen ayam Merawang $(0,40 \pm 0,26 \mathrm{~mL})$ nyata lebih tinggi $(p<0,05)$ dibandingkan ayam Kampung $(0,24 \pm 0,12 \mathrm{~mL})$ atau ayam persilangan SK Kedu $(0,16 \pm 0,10 \mathrm{~mL})$, tetapi tidak memperlihatkan adanya perbedaan warna, konsistensi dan $\mathrm{pH}$ semen. Hasil penelitian juga menunjukkan bahwa diantara tiga ayam lokal tersebut tidak ada perbedaan dalam pergerakan, motilitas, daya hidup serta abnormalitas sperma. Konsentrasi sperma ayam Merawang (4490 million $\mathrm{mL}^{-1}$ ) nyata lebih tinggi dibandingkan ayam Kampung (3245 million $\mathrm{mL}^{-1}$ ) dan persilangan ayam SK Kedu (3751 million $\mathrm{mL}^{-1}$ ). Disimpulkan bahwa ayam Merawang menghasilkan kualitas semen lebih baik dibandingkan dengan ayam Kampung dan persilangan ayam SK Kedu.
\end{abstract}

Kata Kunci: karakteristik, ayam lokal, semen

\section{Introduction}

Increase productivity of local roosters is needed due to some types of Indonesia local roosters are an Indonesian native germplasm that need to be preserved. Local roosters play a role as meat and egg producer, contributed in animal food sufficiency up to $23 \%$ of meat and $40 \%$ of the eggs (Suprijatna, 2010). There is some indication that the demand of local roosters from year to year is increased. The tastes of meat local roosters more preferable, low fat and more organic meat product. This can be seen with establishing a new restaurant with a local roosters menu.

The advantages of local roosters are good adaptability to tropical environment, good mothering ability and resistance to certain diseases. However, there are several obstacles in the development of local roosters. The 
weaknesses of local roosters such as slow growth rate, egg production are low and small body size when compared to Broiler roosters (Dessie et al., 2011), having the nature of broodess, slow sexual maturity, low genetic quality, and relatively expensive price because of high demand which is not offset by increased production (Sulandari et al., 2007). The high demand for local roosters products may threaten the local roosters population if not balanced with conservation.

Problems often found in increasing the production of local roosters is the provision of quality breeds. In search of candidate breeds, rather than being based on the exterior appearance can also be done with the concept of breeding, so as to obtain quality breeds to increase livestock production and value-added or advantages of both types of crossbred roosters (Darwati, 2000). Breeding types of local roosters made to produce the new breeds roosters (proven breed) with a better genetic quality. The quality of local roosters needs to be improved through cross breeding with the aim of increasing the rate of its growth and improve reproductive efficiency, but while maintaining the original characteristics such as coat color of local roosters egg shape, color shell, meat flavor, and texture of the meat. Suprijatna (2010) stated that crosses local roosters can increase their productivity by not changing the characteristics of the product and phenotype.

Application of technology of Artificial Insemination (Al) is one of reproductive technology that can be used to improve the productivity of local roosters by improving the ability of local roosters that have superior production quality to fertilize several females. One of the factors that influence the success of Al is the quality of the semen. Hence the success of Al requires good quality semen. This study aim to compare the semen quality of 3 types Indonesian local roosters and to find out individual variation among breed roosters.

\section{Materials and Methods}

The present study conducted at breeding cages of Faculty of Animal Science and at the Laboratory of Reproduction Rehabili-tation Unit, Faculty of Veterinary Medicine, Bogor Agricultural University during February-May 2016.

\section{Animals}

The experiment was conducted on 15 mature roosters, 1.5 years of age, consist of three different types (5 Merawang, 5 SK Kedu and 5 Kampung). All Roosters were housed in individual cages $\left(50 \times 50 \times 90 \mathrm{~cm}^{3}\right)$, were fed 100 $\mathrm{g} /$ head/day with a commercial diet containing $17 \%$ crude protein, energy metabolism 2229.40 Kcal, $13 \%$ moisture content, crude fiber $6 \%, 3 \%$ fat, $14 \%$ ash, $0.6 \%-1 \%$ phosphorus and $3.0-4.2 \%$ calcium and water were provided ad libitum.

\section{Semen collection methods}

Semen was collected from each roosters 3 times a week for 3 months by the dorsoabdominal and cloaca massage method. All roosters were trained for semen collection, and collected by a trained technician.

\section{Semen evaluation}

Immediately after collection, semen was evaluated macro- and Microscopically. Macroscopyc evaluation were conducted for semen volume $(\mathrm{mL})$, color, consistency and $\mathrm{pH}$. Microscopic evaluation was conducted on the percentage of motile sperm, live sperm, sperm abnormality and sperm concentration.

\section{Macroscopic evaluation}

The semen volume, color and consistency, were visually evaluated. The $\mathrm{pH}$ of semen sample of each roosters was measured using $\mathrm{pH}$ ranged from 6.4 to 8 (Merck special indicator paper).

\section{Microscopic evaluation}

Mass movement was examined by putting a drop of semen on a warm slide under a light microscope (Olympus $\mathrm{CH}$ 20) at $100 \mathrm{x}$ 
magnification. The score assigned between 1+ (total sperm were motionless), 2+ (if the wave thick mass, but slow migratory or mass wave being but a quick move), and $3+$ (wave motion varied rapidly, the eddies were present). Sperm motility was assessed by mixing 1 drop of semen with 4 drops of physiological saline and homogenized. One drop of the mixture was transferred to a clean, warm glass object and covered with a cover glass. The sperm motility was assessed subjectively from 5 fields, 0 (all not moving) to $100 \%$ (all progressive motile). The evaluation was conducted under a light microscope (400x magnification). Sperm motility estimations were performed from 5 different fields in each sample. Percentage of sperm motility was subjectively evaluated on a scale ranging from 0 to $100 \%$.

The percentage of live sperm was evaluated according to Ax et al. (2000). Briefly, a drop of well-mixed semen was mixed with a drop of eosin-nigrosin stain on a glass slide. Another glass slide was used to prepare the smear and dried at heating table $\left(37^{\circ} \mathrm{C}\right) .10$ fields per slide (at least 200 sperm) were directly counted using light microscope (400x magnification). Sperm colored pink was considered nonviable and unstained (clear) cells were counted as a live (Arifiantini et al., 2013). Sperm abnormality, a smear was prepared from a mixture of diluted semen and eosin-nigrosin. The percentage was based on 200 sperm count (Arifiantini, 2012). Sperm concentration of the semen sample was counted by using a Neubauer Chamber. $2 \mu \mathrm{l}$ semen was diluted with $998 \mu \mathrm{l}$ formolsalin, in an $1.5 \mathrm{~mL}$ microtube. Total sperm number per ejaculate was obtained by multiplying the total volume with the sperm concentration.

\section{Data analysis}

The data were analyzed by using Analysis of Variance (ANOVA), followed by the Duncan's multiple range tests to determine significant differences in all the parameters among groups (Steel and Torrie, 1995)

\section{Results and Discussion}

\section{Semen quality of Merawang, Kampung, and SK Kedu}

Generally, poultry semen has a low semen volume and high sperm concentration. This present study macroscopically found no differences among colour, consistency and $\mathrm{pH}$. All roosters demonstrated milky white in color with thick consistency and $\mathrm{pH}$ ranging from $6.94 \pm 0.25$ to $6.97 \pm 0.31$ (Table 1 ). $\mathrm{pH}$ range was still included in the normal range, a factor that could play a role is the technique of semen collection and stimulation of the accessory sex glands. The accessory sex gland fluid is generally alkaline (Bah et al., 2001; Peters et al., 2008; Tuncer et al., 2008).

The study showed that there was a significant difference $(p<0.05)$ on semen volume. Semen volume of Merawang $(0.40 \pm 0.19 \mathrm{~mL})$ was higher than Kampung $(0.24 \pm 0.15 \mathrm{~mL})$ and SK Kedu $(0.16 \pm 0.15 \mathrm{~mL})$ (Tabel 1). In the present study, the semen volume was similar to the results reported for other roosters of different breeds Green-Legged Partridge, Black Minorca, White Crested Black Polish, and Italian Partridge $(0.24-0.52 \mathrm{~mL})$ in previous studies Siudzinska and Łukaszewicz (2008a). According to Malik et al. (2013) the variations among the breeds in semen volume were $0.33 \pm 0.16 \mathrm{~mL}, 0.29 \pm 0.18 \mathrm{~mL}$, and $0.10 \pm 0.10 \mathrm{~mL}$ for red jungle fowl, domestic roosters, and bantam roosters, respectively. This defferences might be related to body weight. Merawang is $2.72 \pm 0.05 \mathrm{~kg}$, Kampung is $2.57 \pm 0.05 \mathrm{~kg}$ and SK Kedu only $2.26 \pm 0.05 \mathrm{~kg}$.

The variation in semen volume among genetic groups may be explained by the normal physiological processes regulating spermatogenesis and respond to the massage technique during semen collection (Tarif et al., 2013). Donoghue et al. (2000) stated that ejaculation volume, which depends on breed, age, individual, season, light and many other environmental factors, is average $0.70 \mathrm{~mL}$ and increase for heavy breeds. 
Table 1 Semen Quality of Merawang, Kampung, and SK Kedu (Means \pm SEM)

\begin{tabular}{lccc}
\hline \multirow{2}{*}{ Parameter } & \multicolumn{3}{c}{ Breed } \\
\cline { 2 - 4 } & Merawang & Kampung & SK Kedu \\
\hline Volume (mL) & $0.40 \pm 0.19^{\mathrm{a}}$ & $0.24 \pm 0.15^{\mathrm{c}}$ & $0.16 \pm 0.15^{\mathrm{b}}$ \\
Color & milky white & milky white & milky white \\
Consistency & thick & thick & thick \\
pH & $6.97 \pm 0.31^{\mathrm{a}}$ & $6.96 \pm 0.25^{\mathrm{a}}$ & $6.94 \pm 0.25^{\mathrm{a}}$ \\
Mass movement & $3+$ & $3+$ & $3+$ \\
Motile sperm (\%) & $81.83 \pm 8.10^{\mathrm{a}}$ & $82.67 \pm 6.50^{\mathrm{a}}$ & $82.93 \pm 6.50^{\mathrm{a}}$ \\
Live sperm (\%) & $90.02 \pm 7.84^{\mathrm{a}}$ & $91.05 \pm 6.30^{\mathrm{a}}$ & $91.45 \pm 6.30^{\mathrm{a}}$ \\
Abnormal sperm (\%) & $3.22 \pm 5.64^{\mathrm{a}}$ & $3.62 \pm 4.55^{\mathrm{a}}$ & $2.99 \pm 4.55^{\mathrm{a}}$ \\
Sperm concentration $\left(10^{6}\right.$ cell $\left.\mathrm{mL}^{-1}\right)$ & $4490 \pm 714^{\mathrm{a}}$ & $3245 \pm 571^{\mathrm{b}}$ & $3751 \pm 571^{\mathrm{b}}$ \\
Total number sperm per ejaculate $\left(10^{6}\right)$ & $2066 \pm 318^{\mathrm{a}}$ & $789 \pm 255^{\mathrm{b}}$ & $613 \pm 255^{\mathrm{b}}$ \\
\hline
\end{tabular}

$\stackrel{a-c}{a}$ Values with different superscripts within a row are significantly difference $(P<0.05)$.

This present study microscopically showed that there were no differences ( $p>0.05)$ among mass movement, sperm motility, live sperm, and sperm abnormality (Tabel 1). Mass movement was $3+$. The percentages of sperm motility, live sperm, and sperm abnormality of the semen were $81.83 \pm 8.10 \%, 82.67 \pm 6.50 \%$, and $82.93 \pm 6.50 \% ; 90.02 \pm 7.84 \%, 91.05 \pm 6.30 \%$ and $91.45 \pm 6.30 \%$; and $3.22 \pm 5.64 \%, 3.62 \pm 4.55 \%$ and, $2.99 \pm 4.55 \%$ for Merawang, Kampung, and SK Kedu, respectively. The study showed that there was a significant difference $(p<0.05)$ on sperm concentration among three types local roosters. Merawang roosters recorded the highest of sperm concentration $\left(4490 \times 10^{6} \mathrm{~mL}^{-}\right.$ $\left.{ }^{1}\right)$ compare to other roosters. No difference was found ( $p>0.05$ ) between Kampung (3245 $x$ $\left.10^{6} \mathrm{~mL}^{-1}\right)$ and SK Kedu $\left(3751 \times 10^{6} \mathrm{~mL}^{-1}\right)$.

According to Malik et al. (2013) and Hermiz et al. (2016) the difference in sperm concentration among roosters breed was also recorded. Malik et al., (2013) have found sperm concentration for Red Jungle fowl, Domestic Roosters, and Bantam Roosters, were 4.44 \pm 9.05 $\times 10^{9} \mathrm{~mL}^{-1}, 2730 \pm 10.5 \times 10^{6} \mathrm{~mL}^{-1}$, and $1830 \pm 7.43$ $\times 10^{6} \mathrm{~mL}^{-1}$, respectively, while Hermiz et al. (2016) reported sperm concentration was 3650 $\times 10^{6} \mathrm{~mL}^{-1}$ to $5890 \times 10^{6} \mathrm{~mL}^{-1}$ among genetic groups of roosters. Tarif et al. (2013) noticed that sperm concentration significantly varied among the line of roosters and varied from $9600 \times 10^{6}$ to $7500 \times 10^{6}$ per $\mathrm{mL}$. The differences in sperm concentration between roosters are suspected to involve many factors such as intake of feed, and the body size could be attributed to their different genetic makeup, and body weight (Malik et al., 2013) also age and season (Elagib et al., 2012). Donoghue et al. (2000) observed the sperm concentration increace for heavy breeds.

Total number sperm per ejaculate were found significant differences $(p<0.05)$ among three types local roosters. Total number sperm per ejaculate of Merawang $\left(2066 \pm 318 \times 10^{6}\right.$ cell per ejaculate) was higher than Kampung ( $789 \pm 255 \times 10^{6}$ cell per ejaculate) and SK Kedu (613 $\pm 255 \times 10^{6}$ cell per ejaculate). The present study of Merawang roosters recorded the highest of total spermatozoa per ejaculate compare reported by Sonseeda et al. (2013) of Thai Indigenous roosters $1477 \times 10^{6}$ cell per ejaculate.

\section{Individual semen quality of Merawang}

This present study macroscopically found no differences between color and $\mathrm{pH}$. All roosters demonstrated milky white in color and $\mathrm{pH}$ ranging from $6.90 \pm 0.10$ to $7.0 \pm 0.05$. Consistency ranged from thick until watery. A variation in the semen volume among individuals on Merawang roosters was 
recorded. It was found that there were significant differences $(p<0.05)$ in semen volume. The greater amounts of ejaculated volume recorded for Merawang number 5 (M5) was $0.66 \pm 0.03 \mathrm{~mL}$ and the lowest in Merawang number (M3) only $0.17 \pm 0.03 \mathrm{~mL}$ (Fig. 1). Bah et al. (2001) reported semen volume of Sahel regional local breeding Roosters to be averaged $0.28 \mathrm{~mL}$. Tuncer et al. (2006) reported semen volume of Denizli Roosters to be $0.70 \mathrm{~mL}$. It also in the same range reported by Peters et al. (2008) 0.37-0.73 mL, for Nigerian indigenous breeds. Mosenene (2009) recorded semen volume was $0.3 \pm 0.10$ to $0.4 \pm 0.10 \mathrm{~mL}$ in 4 South African roosters breeds.

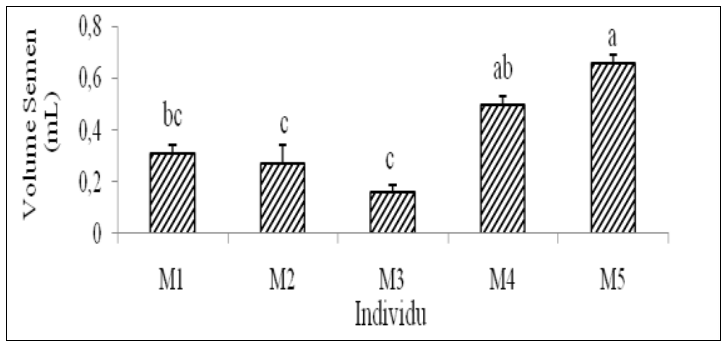

Fig 1. Individuals semen volume of Merawang roosters. M1: Merawang 1; M2: Merawang 2; M3: Merawang 3; M4: Merawang 4; M5: Merawang 5.

This present study microscopically found that there were significant differences $(p<0.05)$ in the mass movement, motile sperm, live sperm, sperm abnormal and sperm concentration. Mass movement ranging from $2+$ to $3+$. From all individual, Merawang number 2 (M2) roosters had lowest motile sperm $(71.67 \pm 2.92 \%)$ and live sperm percentages (80.90 $\pm 2.80 \%)$. However, for M1 motile sperm and live sperm did not differ with roosters M3, M4 and M5. The greatest percentages of motile sperm and live sperm $(83.67 \pm 1.30 \%$ and $91.13 \pm 1.20 \%$ ) were found in the individual roosters M4 and M5, respectively (Fig. 2). Tuncer et al., (2006) determined the sperm motility for Denizli roosterserels and found it to be on average $72.3 \pm 0.08 \%$. Researchers have also found the sperm motility for the White
Leghorn breed to be $83.2 \pm 0.60 \%$, and $77.6 \pm 0.20 \%$ of the New Hampshire (Tuncer et al., 2008).

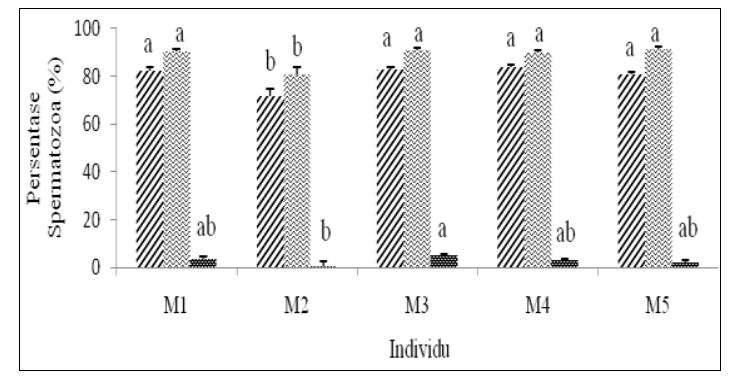

Fig 2. Individuals percentage of motile sperm

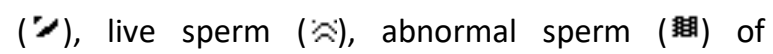
Merawang roosters. M1: Merawang 1; M2: Merawang 2; M3: Merawang 3; M4: Merawang 4; M5: Merawang 5.

The variation in sperm motility among genetic groups could be due to the genetic potential of individual line. Also previously, results of Tuncer et al. (2006), Peters et al. (2008), and Tarif et al. (2013), showed that there were differences in strain with respect to motility. Earlier study conducted by Hermiz et al, (2016) reported that the crossed roosters percentage of live sperms were $93.08 \%$. Tarif et al. (2013) stated that the proportion of live sperms significantly varied from $82.20 \%$ to $87.30 \%$ among the line of roosters. Nevertheless, the high percentage of live sperms in the present study were good enough for routine $\mathrm{Al}$ in poultry.

The results of study showed that there was a significant difference $(p<0.05)$ in sperm abnormality. Average sperm abnormality individual of Merawang, were M1 (3.50 $0.90 \%)$, M2 (0.58 $\pm 2.00 \%), \quad M 3 \quad(4.88 \pm 0.90 \%), \quad M 4$ $(2.90 \pm 0.90 \%)$, and M5 (2.11 $\pm 0.90 \%)$, respectively (Fig. 2). From all individuals, M2 had a lowest sperm abnormality and M3 had highest of sperm abnormality. Based on the results of this study showed that the sperm abnormality was still included in the normal range. Selvan (2007) reported that sperm 
abnormality of Rock roosters was 3.09-5.75\% dependent on influence of age, dietary protein, vitamin $\mathrm{E}$, and calcium.

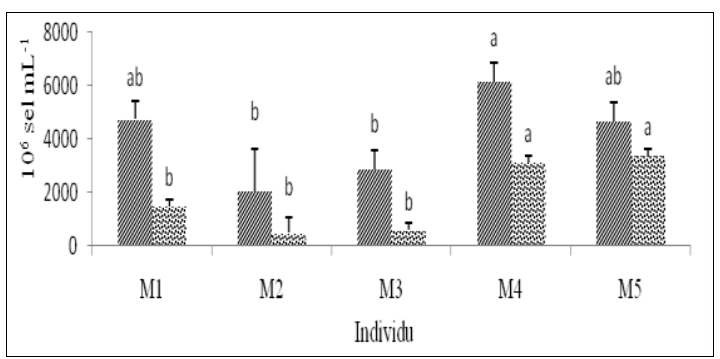

Fig 3 Individuals sperm concentration ( number sperm per ejaculate (i-i) of Merawang roosters. M1: Merawang 1; M2: Merawang 2; M3: Merawang 3; M4: Merawang 4; M5: Merawang 5.

Figure 3 shows sperm concentrations and total number sperm per ejaculate of individual of Merawang. As can be seen, M4 roosters recorded the highest of extreme sperm concentration $\left(6158 \pm 693 \times 10^{6} \mathrm{~mL}^{-1}\right)$ and the lowest sperm concentration in M2 (2066 $\pm 693 x$ $\left.10^{6} \mathrm{~mL}^{-1}\right)$. M5 $\left(3396 \pm 421 \times 10^{6}\right)$ and M4 (3 $110 \pm 421 \times 10^{6}$ ) roosters recorded the highest of total number sperm per ejaculate and the lowest total number sperm per ejaculate in $\mathrm{M} 2$ $\left(486 \pm 942 \times 10^{6}\right)$. The sperm concentration reported in the present study, was higher than that reported by other researchers. Siudzinska and Lukaszewicz (2008b) reported an average sperm concentration of $4700 \times 10^{6} \mathrm{~mL}^{-1}$ in White Crested Black Polish Roosters and $4200 \times 10^{6} \mathrm{~mL}^{-}$ 1 in the Black Minorcas breeds. Tuncer et al. (2008) and Obidi et al. (2008) reported sperm concentrations of $2400 \times 10^{6} \mathrm{~mL}^{-1}$ in Gerze Roosters and $3600 \times 10^{6} \mathrm{~mL}^{-1}$ in Shikabrown Roosters.

\section{Individual semen quality of Kampung}

This present study macroscopically found no differences between color and $\mathrm{pH}$. All roosters demonstrated milky white in color and $\mathrm{pH}$ ranging from $6.91 \pm 0.05$ to $7.0 \pm 0.05$. Consistency ranged from thick until watery. $A$ variation in the semen volume among individuals on Kampung roosters was recorded. It was found that there were significant differences $(p<0.05)$ in semen volume. The greater amounts of ejaculated volume recorded for $\mathrm{K} 1(0.29 \pm 0.03 \mathrm{~mL})$ and $\mathrm{K} 5(0.28 \pm 0.03 \mathrm{~mL})$ and lowest in $\mathrm{K} 3(0.17 \pm 0.03 \mathrm{~mL})$ (Fig. 4).

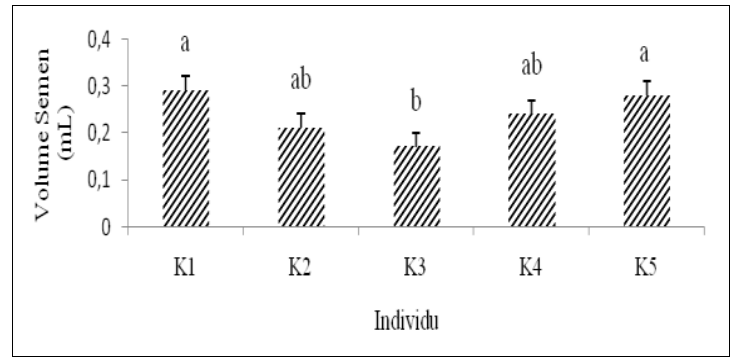

Fig 4 Individuals semen volume of Kampung roosters. K1: Kampung 1; K2: Kampung 2; K3: Kampung 3; K4: Kampung 4; K5: Kampung 5

In this study microscopically, found that there were no differences in motile sperm, live sperm, and sperm abnormality, while sperm concentrations were significantly different $(p<0.05)$ among individuals Kampung roosters. Mass movement ranging from $2+$ to $3+$. All roosters showed motile sperm, live sperm, and sperm abnormality ranging from $81.33 \pm 1.30 \%$ to $84.00 \pm 1.30 \%$; $90.59 \pm 1.26 \%$ to $92.46 \pm 1.26 \%$; and $1.60 \pm 0.91 \%$ to $4.88 \pm 0.91 \%$, respectively Figure 5 showed sperm concentrations and total number sperm per ejaculate of individual of Kampung. Statistical analysis showed that sperm concentration and total number sperm per ejaculate were significantly different $(p<0.05)$. As can be seen, Kampung number 2 (K2) roosters recorded the highest of extreme sperm concentration $\left(5913 \pm 445 \times 10^{6} \mathrm{~mL}^{-1}\right)$ and total number sperm per ejaculate $(1299 \pm 147 \mathrm{x}$ $10^{6}$ ) and the lowest sperm concentration and total number sperm per ejaculate in Kampung number 3 (K3) were $1885 \pm 445 \times 10^{6} \mathrm{~mL}^{-1}$ and $300 \pm 147 \times 10^{6}$, respectively. The sperm concentration in the present study was lower than Mphaphathi et al. (2016) reported an 
average sperm concentration of $6800 \times 10^{6} \mathrm{~mL}^{-1}$ in Venda roosters.

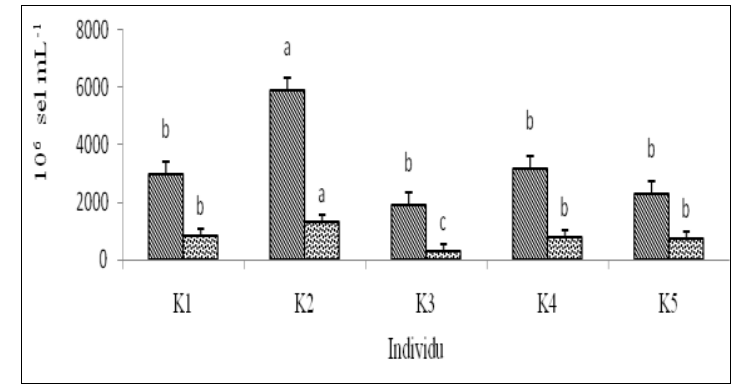

Figure 5. Individuals sperm concentration ( and total number sperm per ejaculate (i-i) of Kampung roosters. K1: Kampung 1; K2: Kampung 2; K3: Kampung 3; K4: Kampung 4; K5: Kampung

\section{Individual semen quality of SK Kedu}

This present study macroscopically found no differences between color and $\mathrm{pH}$. All roosters demonstrated milky white in color and $\mathrm{pH}$ ranging from $6.87 \pm 0.05$ to $6.99 \pm 0.05$. Consistency ranged from thick until watery. A variation in the semen volume among individuals on SK Kedu roosters was recorded. It was found that there were significant differences $(p<0.05)$ in semen volume. The greater amounts of ejaculated volume recorded for SK Kedu number 2 (SK2) $0.26 \pm 0.03 \mathrm{~mL}$ and lowest in SK Kedu number 5 (SK5) $0.09 \pm 0.03 \mathrm{~mL}$ (Fig. 6).

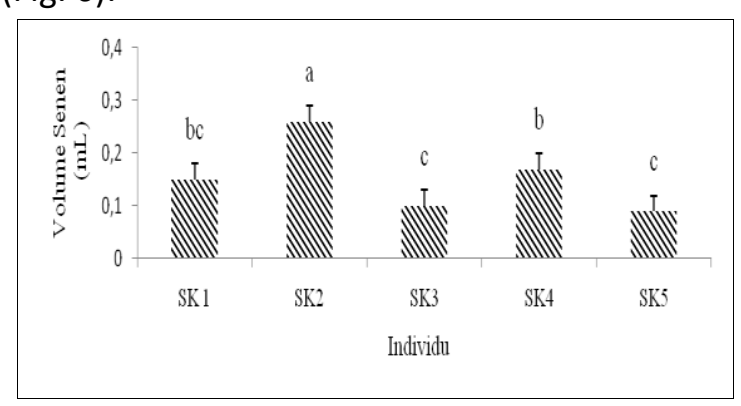

Figure 6 Individuals semen volume of SK Kedu roosters. SK1: SK Kedu 1; SK2: SK Kedu 2; SK3: SK Kedu 3; SK4: SK Kedu 4; SK5: SK Kedu 5.

This present study microscopically found no differences among motile sperm, live sperm, and sperm abnormal. Mass movement ranging from $2+$ to $3+$. All roosters showed motile sperm, live sperm, and sperm abnormality ranging from $81.67 \pm 1.30 \%$ to $85.00 \pm 1.30 \%$; $90.65 \pm 1.26 \%$ to $92.24 \pm 1.26 \%$; and $2.73 \pm 0.91 \%$ to $3.70 \pm 0.91 \%$, respectively.

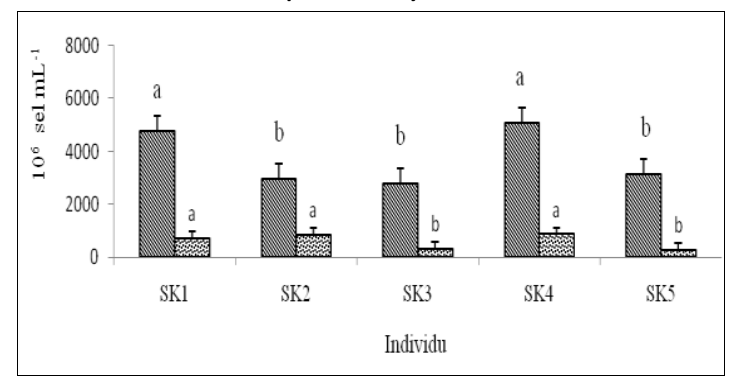

Figure 7 Individuals sperm concentration (\%) and total number sperm per ejaculate (i-i) of SK Kedu roosters. SK1: SK Kedu 1; SK2: SK Kedu 2; SK3: SK Kedu 3; SK4: SK Kedu 4; SK5: SK Kedu 5

Figure 7 showed sperm concentrations and total number sperm per ejaculate of individual of SK Kedu. As can be seen, SK4 (5 073 $\pm 572 \mathrm{x}$ $\left.10^{6} \mathrm{~mL}^{-1}\right)$ and SK1 $\left(4791 \pm 572 \times 10^{6} \mathrm{~mL}^{-1}\right)$ recorded the highest of sperm concentration. The lowest sperm concentration in SK3 $\left(2801 \pm 572 \times 10^{6} \mathrm{~mL}^{-1}\right)$. SK4 $\left(876 \pm 127 \times 10^{6}\right)$, SK2 $\left(849 \pm 127 \times 10^{6}\right)$ and SK1 $\left(736 \pm 127 \times 10^{6}\right)$ recorded the highest of total number sperm per ejaculate. The lowest total number sperm per ejaculate in SK5 $\left(294 \pm 127 \times 10^{6}\right)$. Tuncer et al., (2008) recorded roosterserel sperm concentrations of $2420 \pm 0.02 \times 10^{6}$ sperm/ mL, while other researchers state sperm concentrations of $3530 \pm 1.00 \times 10^{6} \mathrm{sperm} / \mathrm{mL}$, $2200 \times 10^{6} \mathrm{sperm} / \mathrm{mL}, \quad 1870 \pm 0.20 \times 10^{6}$ sperm $/ \mathrm{mL}$ for White Leghorn roosterserels and $3320 \times 10^{6} \mathrm{sperm} / \mathrm{mL}$, and $3347 \times 10^{6} \mathrm{sperm} / \mathrm{mL}$ for the New Hampshire breeds (Tuncer et al., 2006, 2008; Peters et al., 2008). This present study concluded Merawang had good semen quality better than Kampung and SK Kedu roosters. Evaluated individually also showed different quality of semen.

\section{Conclusions}

The study of raw semen characteristics of three local roosters concluded that Merawang roosters had good semen quality better than 
Kampung and SK Kedu roosters. Semen volume of Merawang was higher compare to Kampung or SK Kedu but no difference on semen color, consistency and semen $\mathrm{pH}$. Sperm concentration of Merawang (4490 million $\mathrm{mL}^{-1}$ ) was significantly higher than Kampung (3245 million $\mathrm{mL}^{-1}$ ) and the SK Kedu roosters (3751 million $\mathrm{mL}^{-1}$ ).

\section{References}

Arifiantini RI. 2012. Teknik koleksi dan evaluasi semen pada hewan. IPB Pr., Bogor

Arifiantini RI, B Purwantara, TL Yusuf and D Sajuthi. 2013. The quality of stallion semen in skim milk and dimitropoulos extenders preserved at $5{ }^{\circ} \mathrm{C}$ and ambient temperature supplemented with different sugar. Med. Pet. 36 (1): 45-51. http:// medpet .journal.ipb.ac.id/. doi:10.5398 /medp et.2013.36.1. 45.

Ax RL, M Dally, BA Didion, RW Lenz, CC Love, DD Varner, B Hafez and ME Bellin. 2000. Semen evaluation. In: Hafez B and ESE Hafez. 2000. Reproduction in Farm Animals. $7^{\text {th }}$ ed. Philadelphia (US): Lippincott Williams \& Wilkins. 365-389.

Bah GS, SUR Chaughari and JD Al-Amin. 2001. Semen characteristics of local breeder Roosters in the Sahel region of Nigeria. Revue Elev. Med. Vet. Pays trop. 54: (2) 153-158.

Darwati S. 2000. Produktivitas Ayam Kampung, Pelung dan resiprokalnya. Med. Pet. 23: 2.

Dessie T, T Taye, N Dana, W Ayalew and O Hanotte. 2011. Current state of knowledge on phenotypic characteristics of indigenous roosters in the tropics. J. Poult. Sci. 67:507-516. http://dx.doi.org/10.1017 /S0043933911000559.

Donoghue AM and GJ Wishart. 2000. Storage of poultry semen. Anim Reprod Sci, 62: 213-232.

Elagib HAA, NA Musharaf, SA Makawi and HE Mohamed. 2012. The effects of age and season on semen characteristics of White Leghorn Roosters under Sudan conditions. Int. J. Poult. Sci. 11 (1): 47-49.

Malik A, AW Haron, R Yusoff, M Nesa, M Bukar and A Kasim 2013. Evaluation of the ejaculate quality of the red jungle fowl, domestic roosters, and bantam roosters in Malaysia. Turk. J. Vet. Anim. Sci. 37:564-568. doi:10.3906/vet-1107-26

Mosenene TMB. 2009. Characterization and cryopreservation of semen of four south african roosters breeds. Thesis. University of the Free State. Bloemfontein

Mphaphathi ML, MM Seshoka, D Luseba, B Sutherland and TL Nedambale. 2016. The characterisation and cryopreservation of Venda roosters semen. Asian Pacific J. Rep. 5(2): 132139. http://dx.doi.org/ 10.1016/j.apjr.2016. 01.009.

Obidi JA, BI Onyeanusi, PI Rekwot, JO Ayo and T Dzenda. 2008. Seasonal variations in seminal characteristics of Shikabrown breeder Roosters. Int. J. Poult. Sci. 7: 1219-1223.

Parker HM and CD McDaniel. 2006. The immediate impact of semen diluent and rate of dilution on the sperm quality index, ATP utilization, gas exchange and ionic balance of broiler breeder sperm. Poult. Sci. 85, 106-116.

Peters SO, OD Shoyebo, BM Ilori, MO Ozoje, CON Ikeobi and OA Adebambo. 2008. Semen quality traits of seven strain of roosters raised in the humid tropics. Int. J. Poult. Sci. 7 (10): 949-953.

Selvan ST. 2007. Influence of dietary protein, calcium and vitamin-E on the semen quality in broiler breeder males. Tamilnadu J. Vet. Anim. Sci. 3 (2): 60-64.

Siudzinska A and E Lukaszewick. 2008a. Effect of semen extenders and storage time on sperm morphology of four roosters breeds. Appl. Poult. Res. 17: 101-108.

Siudzinska A and E Lukaszewick. 2008b. The effect of breed on freezability of semen of fancy fowl. Anim. Sci. Pap. Rep. 4: 331-340.

Sonseed P, T Vongpralub and B Laopaiboon. 2013. Effects of environmental factors, ages and breeds on semen characteristics in Thai Indigenous roosters: a one-year study. Thai J Vet Med. 43(3): 347-352.

Steel RGD and JH Torrie. 1995. Prinsip dan Prosedur Statistika: Suatu Pendektan Biometrik. Sumantri B, penerjemah. Gramedia Pustaka Utama. Jakarta.

Sulandari S, MSA Zein, S Payanti, T Sartika, M Astuti, T Widyastuti, E Sujana, S Darana, I Setiawan and D Garnida. 2007. Keanekaragaman sumber daya hayati ayam lokal Indonesia. Pusat Penelitian Biologi. Lembaga Pengetahuan Ilmu Indonesia. Bogor.

Suprijatna E. 2010. Strategi pengembangan peternakan ayam lokal Indonesia. Universitas Diponegoro. Semarang.

Tarif AM, MMU Bhuiyan, RN Ferdousy, NS Juyena and B R Mollah. 2013. Evaluation of semen quality among four roosters lines. J. of Agriculture and Vet. Sci (IOSR-JAVS). 6 (5): 7-13.

Tuncer PB, H Kinet and N Ozdogan. 2008. Evaluation of some spermatological characteristics in Gerze Roosters. Ank. Univ. Vet. Derg. 55: 99-102.

Tuncer PB, H Kinet, N Ozdogan and O Demiral. 2006. Evaluation of Some Spermatological Characteristics in Denizli Roosters. J. Fac. Vet. Med. Univ. Erciyes, 3(1) 37-42. 